\title{
Spin and censorship
}

\section{Exposing and opposing censorship: Backfire dynamics in freedom-of-speech struggles}

\section{ABSTRACT}

Censorship can backfire because it is usually viewed as a violation of the right to free expression, which is widely valued as an ideal; under the Charter of the United Nations, freedom of expression is a universal human right. Backfire occurs, for example, when censorious attacks on a film or book cultivate increased demand for the forbidden work rather than restrict access to it. Censors can inhibit this backfire effect in various ways, including covering up the censorship, devaluing the target, reinterpreting the action, using official channels, and using intimidation and bribery. These five methods to inhibit backfire from attacks on free speech are illustrated by a variety of cases, including attacks that backfired and ones that did not. This analysis provides guidance for effectively opposing attacks on free expression.

\section{SUE CURRY JANSEN}

Muhlenberg College

and

BRIAN MARTIN

University of Wollongong

7 HE NORMAL aim of censorship is to suppress speech, publications and other forms of expression in whole or part. But sometimes the act

1 of censorship creates more attention to, and support for, the censored work and its creator than would have occurred without the intervention of 


\section{THE PUBLIC RIGHT TO KNOW}

censors. This process, which we call 'backfire', is most likely to occur in societies that place a high value on freedom of expression. In such contexts, a case of censorship may not just be perceived as an isolated incident, but as a larger threat that contains the potential to erode the foundations of the political system itself. Censors are always on precarious terrain in democratic societies; that is why they prefer to operate in secret. When, however, censors' interventions are 'legible and visible' (Sennett, 1980), and these interventions are perceived to be unjust, backfire is more likely to occur.

A common form of backfire occurs when special interest groups such as churches call for bans or boycotts of a specific film or novel. The ensuing controversy sometimes receives extensive coverage in news media because the professional ideology of journalism places a high value on freedom of expression. Such public controversy makes many more people aware of the novel, film, performance or work of art and may well attract larger audiences or readerships to it.

Even if the work is successfully suppressed, this kind of censorship cultivates an audience for clandestine sales of the work, and such access is usually only available at premium prices. The power of forbidden fruit can also create a pent-up demand and spawn booming businesses in border towns. Indeed because of the predictability of this kind of backfire, claims of being censored can be used instrumentally as marketing tools, sometimes with spectacular success. A recent example is Mel Gibson's promotion of The Passion. Claiming that Jews opposed release of the film before any Jewish spokespersons had publicly expressed views on the subject, Gibson has generated a controversy that was so widely covered in the press that even the Pope entered the fray - a film mogul's dream come true! (Rich, 2003).

In secular societies, where official censorship or regulation of morals is limited, such protests are more likely to function as sideshows that channel attention away from scrutiny of more profound and systemic forms of information control: secrecy, propaganda and disinformation by governments and corporations. When systemic censorship is exposed to the full light of day - a rare occurrence, which marks a breach in routine government and corporate practices - it opens the door to a far more serious and significant backfire dynamic: outrage and anger at the very existence of, or attempt at, censorship.

In theory, then, outrage at the very idea of censorship is a powerful tool for advocates of free expression. After all, freedom of expression was a founding tenet of the Enlightenment philosophies that gave birth to liberal democracies. 
Yet, it is well known that free expression is given widespread lip service in the same contexts in which censorship is widely practised (Herman and Chomsky, 1988; Jansen, 1988; Keane, 1991). This suggests that there must be processes that inhibit outrage against censorship and disinformation.

\section{Attacks that backfire}

To gain insight into the dynamics of censorship, it is useful to look more closely at some attacks that do backfire. When violence is used against nonviolent protesters, this often is seen as unjust. For example, perhaps a hundred black South Africans were killed when white police opened fire on a largely peaceful demonstration in the town of Sharpeville in 1960 (Frankel, 2001). The killings were widely seen as disproportionate to anything that the protesters had done. The Sharpeville massacre generated enormous outrage internationally, leading to much stronger rejection of apartheid and actions against it.

The reaction to the Sharpeville massacre is one example of what nonviolence researcher Gene Sharp (1973) calls 'political jiu-jitsu'. When peaceful protesters are attacked with violence, this can rebound against the attackers, a dynamic that Sharp likens to the sport of jiu-jitsu, in which the strength and force of an opponent are used against that opponent. Other examples of political jiu-jitsu include:

the reaction to killing of hundreds of protesters in Russia in 1905 on what became known as 'Bloody Sunday';

- the reaction to the brutal beating of Indian satyagrahis (nonviolent activists) in 1930, part of the salt satyagraha led by Gandhi;

- the reaction to Indonesian troops killing hundreds of mourners at a funeral in Dili, East Timor in 1991;

the reaction to the killing of several university students by Indonesian police in 1998.

In each case, there was a tremendous upsurge of support for the nonviolent targets of official violence; it was often accompanied by divisions among the attacking group.

Sharp focussed his attention on violent attacks on nonviolent resisters, but it is reasonable to generalise from his framework to include other forms of attacks (Jansen and Martin, 2003; Martin and Wright, 2003). Any clear violation of a widely accepted social norm can potentially rebound against the violator, a process that we call 'backfire'. Our attention here is on norm 
violations by those in positions of power or authority, in particular actions that are seen as unjust or disproportionate. Although censorship seems on the surface to be quite different from violent attacks on protesters, there is a striking similarity in the types of processes involved in preventing or amplifying backfire.

Censorship is a violation of the norm of free expression, and thus can potentially backfire. However, it is apparent that most censorship does not trigger outrage. This can be attributed to various methods that inhibit the backfire effect. Looking at a range of cases, it is possible to observe the presence of recurring techniques that inhibit backfire from censorship: covering up the censorship, devaluing the target, reinterpreting the action, using official channels, and intimidating or bribing key participants.

In the following sections, we examine each of these methods of inhibition, and examine strategies for overcoming them.

\section{Covering up censorship}

Covering up (censoring) censorship means hiding its very existence or reducing its visibility. This is an effective and widely practised means of inhibiting backfire because people cannot become outraged if they do not know that censorship is occurring. Concealing censorship is also the routine practice of most modern governments and corporations, albeit a practice that operates under other names. Agencies can legitimately pursue goals such as protecting personal privacy, advancing national security, encouraging creativity and innovation, protecting investments, or protecting the innocence of minors, yet at the same time use these goals to mask control of information beyond the necessary minimum.

This is, in short, covert censorship, practised by stealth. Government agencies and corporations make decisions and implement policies, usually in times of crises, which are designed to keep sensitive information from circulating. Initially justified as a means to defend national security, combat crime, or prevent industrial sabotage, reactive censorships almost invariably become proactive as they are bureaucratised and routinised into administrative procedures and operational practices. The blanket expands to cover up administrative errors and abuses, and to prevent circulation of information that could (in the inherently cautious judgements of bureaucrats) trigger public concern or criticism. The end result is the kind of thirty-year moratorium on 
the release of government documents into the public domain in Australia and Britain.

Within US government agencies, status is attached to having access to classified documents; it marks one's place in the formal and informal hierarchies of government agencies. The more access a bureaucrat has, the closer he or she is perceived as being to the inner circles of power. As a result aspirants to higher office routinely seek to have the projects they are working on classified because it elevates their importance among their peers. These pecking order politics also contribute to continual expansion of the elastic blanket of government secrecy. Sunshine clauses and the freedom of information laws are reactions against surplus government secrecy and bureaucratic displacement of goals, but such procedural measures are vulnerable to being watered down or overruled. For example, President George W. Bush sealed, by executive order, access to sensitive documents from his father's administration which had been scheduled to be released under the Freedom of Information Act.

A sobering cautionary note is nevertheless in order here: David Ewing (1977) demonstrates that government secrecy pales in comparison to the kind of secrecy and abridgements of free expression that prevail in private corporations.

Spy agencies, otherwise known as intelligence organisations, are, of course, publicly sanctioned practitioners of censorship and its alter ego, disinformation (intentionally incorrect information). Within spy agencies themselves, information is supposed to be available only on a 'need to know' basis. This practice is so widely accepted that the restraints it imposes on free speech are seldom even considered legitimate matters for discussion. When constraints are imposed on the media, however, these restrictions are more likely to be contested. In times of war and national emergency, spy agencies may ask the mass media not to report certain matters. When the media acquiesce, the very existence of censorship is unknown to citizens. In Australia, D-notices, used to censor the media, seldom receive publicity. In all US wars since Vietnam, press censorship and control has been overt and strictly enforced. In the 2003 Iraq conquest, however, military control of the press was practised with remarkable public relations savvy by 'embedding' reporters in military units. To qualify, reporters had to train with the troops, and essentially become part of the unit they would report on. To be sure, war is dangerous and 


\section{THE PUBLIC RIGHT TO KNOW}

the embedding policy provided some minimal physical safety for reporters as well as ensuring their loyalty to the troops they were serving with. Some reporters are now beginning to admit that the apparent openness of the military policy was, in fact, accompanied by extensive media self-censorship (Johnson, 2003).

In some instances, the law is used to enforce the secrecy sought by spy agencies. The US Patriot Act authorises the FBI to demand records from libraries and includes stiff penalties on librarians for revealing that requests have been made. Requesting a patron's records is a violation of privacy rather than censorship, but it involves a process that is parallel to and essentially an extension of the operations of spy agencies. Moreover, the chilling effect that the surveillance policy may have on patrons, on librarians responsible for building collections, and perhaps on scholarship may in time accomplish the same ends as censorship (American Library Association, 2003).

In many court cases in which an individual sues a corporation or government, for example over wrongful dismissal, a settlement is reached, often with a payment to the individual. In such cases the settlement frequently includes a clause barring the individual from discussing the case publicly in future, including the very existence of the clause. These 'confidentiality agreements', better described as silencing or gagging clauses, serve a dual role, both as censorship and as a means of hiding the censorship. Such gags may also be imposed, by extension, on employees of an organisation that has participated in a settlement; employees familiar with but not directly involved in the charges may also become subject to threats of legal action if they speak about the contested events.

Nominally, the existence of a silencing clause is apparent; an inquisitive journalist may be told that a settlement prevents the parties from speaking about the case. But this reduces the news value of the case, reducing further coverage and thus ending the matter as far as most people are concerned. For example, outspoken biologist Ted Steele was dismissed from the University of Wollongong in February 2001; eventually, following two court cases and long negotiations, a settlement was reached that included a silencing clause. The dismissal, previously given prominent attention in the media, immediately dropped from sight (Martin, 2002).

The most obvious challenge to cover-ups, including cover-ups of censorship, is exposure. Investigative journalism and whistleblowing are among the 
tools that can magnify and amplify backfire from censorship.

The NSW Crime Commission has the power to seize assets suspected of being illegally acquired. In one case, a woman's car and property were seized and sold for more than half a million dollars; her crime was to steal clothing worth less than $\$ 500$. The Crime Commission can get away with gross abuses because it operates under heavy secrecy and with little formal accountability. Media investigations and exposures (Mercer, 2003a, b) - and the willingness of some victims to speak out - are vital for challenging both the official abuse and the accompanying censorship.

Another potent challenge is to refuse to abide by silencing demands. This occurred when Phillip Bonaffini talked to the Chicago Tribune about his wife's death, thereby violating the terms of a settlement that included a confidentiality agreement. Bonaffini's wife had died of an infection she caught at Bridgeport Hospital; the hospital made a payment to Bonaffini as part of a settlement. After Bonaffini spoke to the Tribune, the hospital sued for breach of contract. The suit backfired: it generated sympathy for Bonaffini, who spoke of the tens of thousands of patients who die each year from preventable infections. This sympathy, in turn, mobilised antipathy towards the hospital, which promptly dropped the case (Herszenhorn, 2003).

\section{Devaluing the target}

Devaluing the target makes attacks seem less objectionable, at least to most people. Censorship of liars and thieves does not generate the same outrage as censorship of courageous dissidents. Therefore it is predictable that those who want to curtail free speech will denigrate targets and critics.

A tactic of 'slime and defend' (Krugman, 2003) was used by the Bush Administration against former US Ambassador Joseph Wilson. In early 2002, Wilson was commissioned by the CIA to investigate reports that Iraq had purchased uranium from the West African country Niger; he concluded that this claim was baseless. It was nevertheless included in President Bush's 2003 State of the Union speech. In a 14 July 2003 newspaper column, syndicated journalist Robert Novak revealed that Wilson's wife, Valerie Plame, was an undercover CIA operative. Novak's source allegedly came from high in the Bush administration; the leak was apparently in retaliation against Wilson. It is a felony to expose a CIA agent. The administration, under pressure from the Democrats and the press over the leak, went on the offensive against Wilson. 
He was falsely described in an editorial in The Wall Street Journal as an 'open opponent of the U.S. war on terror' (Krugman, 2003, p. 1). Wilson, in fact, supported the war on terror, but not the war on Iraq, because it had no obvious connection to the September 11 terrorist attacks. Right-wing politicians and pundits launched intensive attacks on Wilson's patriotism and competence.

Andrew Wilkie's experience bears some resemblance to the Wilson case. Wilkie, who worked for the Office of National Assessments, one of Australia's intelligence organisations, resigned in March 2003 and spoke out against the Government's use of intelligence about Iraq. Bodies such as ONA are based on secrecy and censorship whose details are covered up; Wilkie broke through this process and caused the Government great embarrassment (Cadzow, 2003). One of the techniques used by the government to reduce backfire was to attack Wilkie personally, both in Parliament and via willing journalists (e.g., Henderson, 2003). The Government's denigration of Wilkie was not very effective though, with various stories and letters exposing and condemning the personal attack on him (e.g., Seccombe, 2003).

David Irving's case represents an attempt to suppress ideas that have nothing to do with national security or corporate reputation. Rather it is about ideas that are widely discredited and, to a significant proportion of the population, detestable. Irving is an historian who has written many books, especially about Nazi Germany. From the 1980s, Irving became increasingly critical of conventional views on the Holocaust and supportive of the view that the Nazis had no programme of mass killing of Jews. Though Irving's claims about the Holocaust were weak and deceptive at a scholarly level (Evans, 2001), he still provided a more credible public face on the issue than most other Holocaust revisionists.

Twice in the 1980s, Irving visited Australia without major incident, though some of his scheduled talks were cancelled because of his views (Dawson, 1986). Since the 1990s, Irving has been repeatedly denied entry to Australia. This refusal to allow Irving an opportunity to express his views in person in Australia has been aided by personal attacks on Irving, which charge that he lacks appropriate scholarly credentials and that he is a Holocaust revisionist. The ban has drawn much greater attention to Irving's work than he received earlier when he visited the country. In 1993, most of Australia's 'leading newspapers and civil liberties groups ... called on the Government to lift the ban, arguing that it was counter-productive and likely to give $\mathrm{Mr}$ 
Irving's views a higher status than they deserved.' (Milliken, 1993). Indeed, the majority of Australian media coverage of Irving has concerned censorship of him and his work rather than critical analyses of the merit of his ideas.

\section{Reinterpreting events}

Reinterpreting events is widely used to justify restraints on free expression. Rather than saying, 'we are restricting your free speech', the censors offer the paternalistic claim, 'we are protecting you' or 'we are acting in your best interests'.

Defamation laws are widely used to prevent free speech. Australia and Britain have highly restrictive defamation laws; there are innumerable cases in which these are used to block free speech, for example to prevent media from exposing corruption (Barendt et al., 1997; Pullan, 1994). In the United States, where the First Amendment gives the appearance of greater protection of free speech, defamation threats and legal action are widely used by governments, corporations and professionals to deter and punish critics. Many of these cases fit the category of Strategic Lawsuits Against Public Participation, or SLAPPs, which are legal actions designed to intimidate people from speaking out (Pring and Canan, 1996).

In the US many journalists report that the biggest obstacle they face in getting controversial stories published or broadcast does not come from advertisers or from business managers per se, but rather from the in-house legal departments of the media organisations themselves. In all major media organisations controversial stories must be routinely vetted by lawyers for anything that might result in litigation or threats of litigation; the offending passages or stories are just as routinely expurgated. Cases where the journalists trump the lawyers are unusual. Principled managers who believe that the public good from releasing a controversial story outweighs the risks, hassles and costs of litigation are a rare breed. Publication of The Pentagon Papers and the Watergate story are landmarks in the history of late 20th century US journalism because they broke with standard practice, not because they exemplify it. More often the legal staff of media organisations function as zealous censorial surrogates who act on behalf of advertisers, government and, of course, their own corporate media owners.

Despite the extensive evidence that defamation law so often serves as a form of censorship, it continues to be justified on the grounds that it protects reputations. Yet there is surprisingly little solid evidence that it actually does 
protect reputations. The ordinary person who is slandered by acquaintances or co-workers will seldom find it of any benefit to launch an action for defamation. Nor can a person libelled on television easily obtain redress. Defamation actions are incredibly costly, slow and procedural. They are not much use except to those who are rich and powerful. Yet despite its serious limitations, defamation law is widely seen as having to do with protecting reputations, thus obscuring its serious effects on free speech.

Intellectual property law is sometimes used for the purposes of suppressing free expression. The systems of copyright and patenting are normally justified as methods for encouraging creativity and innovation by the contradictory means of granting a temporary monopoly over the things created. This monopoly offers a tool for censorship; by denying others the right to reproduce or quote materials, their expression can be blocked. For example, Scientologists attempted to censor their critics, who put high-level Scientology protocols on email lists as a form of exposé, by suing for breach of copyright (Grossman, 1995).

Similarly, the imposition of filtering software is said to be about protecting people, not censorship. In this case, like many others, reinterpretation operates by directing attention to the beneficial effects of a policy and diverting it away from free speech issues.

\section{Official channels}

Official channels can help to reduce backfire by providing an apparently fair means of dealing with free speech controversies. Official channels include press councils, courts, ombudsmen, mediation procedures, parliaments and a host of other mechanisms. Though in many cases these procedural mechanisms give only the illusion of fairness, they dampen outrage by their slowness, their procedural complexity, their dependence on experts, their opaqueness and their reputation as neutral arbiters.

Whistleblowers, who speak out in the public interest, routinely suffer reprisals. Seeking justice, they turn to internal grievance procedures or to external bodies such as ombudsmen and anticorruption commissions. These official channels give the appearance of dispensing justice, thereby reducing backfire. In practice, few of these channels help whistleblowers more than a small fraction of the time (De Maria, 1999): they give only the appearance of providing justice. 


\section{Intimidation and bribery}

Intimidation can inhibit backfire from attacks on free speech. For example, the US Patriot Act has severe penalties for those who reveal the existence of information gathering exercises. Threats of defamation litigation deter many exposés. Raw fear is perhaps the greatest silencer of them all. Ostracism is an extremely powerful and easy-to-use method of pressuring others (Williams, 2001). Fears of loss of the respect of family, friends and co-workers can be powerful deterrents to free expression, as are fears of loss of reputation, income or career advancement. Brute force is also a very real threat is some contexts.

Bribery is another tool that is frequently used to prevent backfire. Many whistleblowers accept settlements that contain silencing clauses: refusing to accept these clauses may mean no money is forthcoming. Whistleblowers are seldom in financial positions that would allow them to refuse compensation because their legal claims are typically based on damages for loss of income that resulted from retaliatory dismissals from employment.

An effective way to counter intimidation is to expose it. Sydney high school student James Giugni, as part of his English examination for the Higher School Certificate, wrote an original essay about an asylum seeker, including fantasies of killing the prime minister. The Board of Studies wrote to Giugni saying that his essay was a 'non-serious response', threatening to fail him for the examination, quite a serious penalty. The board encouraged Giugni to write if there were 'mitigating circumstances'; he immediately did write, but received no response. His follow-up emails and phone calls met a similar stonewalling fate (a scenario typical of what happens to whistleblowers with official channels). More effective in countering this censorship and intimidation were calls from Giugni's father and teacher. What really made a difference, though, was a prominent story in the Sydney Morning Herald (Pryor and Vallejo,2002); subsequent letters to the editor were highly critical of the Board of Studies.

Humorist Al Franken (2003) wrote a book that he titled Lies and the Lying Liars Who Tell Them: A Fair and Balanced Look at the Right. Fox News sued Franken for using the phrase 'fair and balanced', which it claimed as a trademark. This attack backfired when Franken refused to be intimidated and instead publicised the legal action, which the judge dismissed as "wholly without merit'. Sales of the book shot up. Fox also denigrated Franken as a 'C- 


\section{THE PUBLIC RIGHT TO KNOW}

level political commentator' and as 'shrill and unstable', a personal attack that was ridiculed as being far from 'fair and balanced' (Hirschkorn, 2003).

In addition to these specific tactics for suppressing or deflecting backfire through bribes and intimidation, there are far more pernicious and pervasive forms of bribery and intimidation that have historically taken hold in advanced liberal democracies (Carey, 1995). First systematically identified and valorised by Walter Lippmann $(1922,1925)$, this post or neo-liberal approach denigrates citizens' intellectual capacity to participate effectively in the political process, which is characterised as inherently too complex for them to comprehend. Lippmann (1925,p.47) compared the citizen of post World War I America to 'a deaf spectator in the back row, who ought to keep his mind on the mystery off there, but cannot quite manage to keep awake'. Public affairs are 'in no convincing way his affairs'; the deaf spectator is, in Lippmann's view, best served by leaving government to the experts, specialists and technocrats - the 'insiders' - who are best qualified to govern.

Edward Bernays, a contemporary of Lippmann's, who is widely referred to as 'the father of public relations', claimed that Lippmann provided the theory and he provided the method: public relations (Bernays, 1983; Tye, 1998). In the US today, there are more PR practitioners than journalists (Stauber and Rampton, 1995); a vast apparatus of globally networked firms is now dedicated to shaping public perceptions of products, corporations, industries, nations, policies, people including candidates for public office, social issues and even war. The function of PR 'spin' (Ewen, 1996) is to misinform the public: to purposively obfuscate so that it does, indeed, become extraordinarily difficult even for proactive citizens to become well-informed on contested public issues such as the environment, foreign policy or telecommunication regulation. Most ordinary citizens do not have the time or resources necessary to undertake the independent research which would allow them to cut through the spin. When they do dare to express unpopular views, their right (qua qualifications) to speak will often be challenged by experts and insiders and, if the dissident citizen gets media attention, the PR spin machine may target her or him for public humiliation and harassment.

The proliferation of spin encourages public cynicism and apathy, which, in turn, allows Lippmann's 'insiders' to rule with impunity. Cynicism and apathy silence and alienate potential critics of corporate and public policy. They encourage citizens to surrender political sovereignty for the 'bribe' of 
consumer sovereignty (Ewen, 1976; Smythe, 1981). They make it possible for censorship to become the norm and serve as corrosive agents that reduce the ideal of free expression to a form without substance. In short, if people don't care, don't believe in the possibility of reform, don't trust their convictions, don't believe they can make a difference, don't speak up, then backfire loses its trigger.

\section{Lomborg backfire}

Bjørn Lomborg, an associate professor of statistics at Århus University in Denmark, started looking into claims about environmental problems and ended up writing a book, The Skeptical Environmentalist (Lomborg, 2001), that argued environmental problems are not as bad as often portrayed. The book was lauded by opponents of the environmental movement. Lomborg's experiences illustrate all the methods of inhibiting backfire as well as the way in which expert authority is sometimes used and abused to silence and discredit challengers.

Environmental scientists were critical of the book and attacked its methods and conclusions, often in highly emotional terms. They also attacked Lomborg himself, for example for having inappropriate qualifications or, more seriously, for being a liar or fraud, an attempt at devaluation.

Among the hostile responses were an editorial and articles in the January 2002 issue of Scientific American .Lomborg, after Scientific American's editor refused to give him a chance to respond in the same issue, 'posted a response on his own website [www.lomborg.com], in which he reproduced Scientific American's attack and commented on it paragraph by paragraph. The reaction of the magazine was to demand that he remove this "dialogue" from the internet or be sued for infringement of copyright' (Schoenbrod, 2002, p. 53). This was an attempted cover-up backed by intimidation, masking censorship under the cloak of protecting intellectual property.

The attacks on Lomborg appear to have backfired. Sales of The Skeptical Environmentalist were reported to have quadrupled after the Scientific American articles. Jeff Harvey, a critic of Lomborg's, "acknowledges that the venom with which Lomborg was attacked may have been counterproductive" (Giles, 2003, p. 218).

Scientists critical of Lomborg reported him to the Danish Committees on Scientific Dishonesty, which investigated and found him guilty of some 


\section{THE PUBLIC RIGHT TO KNOW}

misconduct. However, this finding 'definitely served to propel Lomborg and his controversial ideas back into the headlines at a time when interest had at last begun to wane' (Giles, 2003, p. 218).

\section{Conclusion}

Actual censorship cases are almost always highly complex. In order to highlight regular features of these complex cases, we have presented a simple model of censorship dynamics. In short, many people support free expression and react against censorship as a violation of a valued social norm. This reaction can be inhibited in five main ways: covering up the censorship, devaluing the target, reinterpreting the action as something other than censorship, using official channels to give the appearance of fair play, and intimidating or bribing participants in the struggle. These methods of inhibition are often quite effective, but they can be countered.

Cover-ups of censorship can be exposed through leaks, whistleblowing and investigative journalism.

Devaluation of targets can be countered by arguing for the value of all people, by exposing double standards and by exposing the technique of devaluation.

Reinterpretation of actions can be challenged by making the case for the central importance of free expression. This is part of the ongoing struggle over meanings of events.

Use of official channels to create a false appearance of justice can be countered by exposing the failure, and sometimes the corruption, of official bodies. It can also be used as a rallying point to refocus people's attention on issues of justice and fairness.

- Intimidation can be opposed by refusing to be intimidated; and both intimidation and bribery can be made to backfire by exposing them.

Some instances of attempted censorship are more readily exposed and opposed due to availability of committed, skilled and well-connected supporters. For example, Bjørn Lomborg's difficulties were taken up by a number of conservative, anti-environmentalist and pro-business commentators; Andrew Wilkie's challenge to the Australian Government's Iraq policy had a receptive audience among numerous opponents of the attack on Iraq. On the other hand, many victims of censorship lack skills, confidence, access and support, so their cases do not become known to a wider audience. 
With a better understanding of the dynamics of censorship, proponents of free expression will be better able to counter the usual methods of inhibiting backfire. As more people are prepared to expose and oppose attacks on free expression, potential censors, realising the risks, will be more reluctant to act. An active, alert, and well-prepared constituency is the best protection for free expression.

\section{References}

American Library Association, www.ala.org/washoff/patriot.html (accessed September 22, 2003).

Barendt, Eric, Laurence Lustgarten, Kenneth Norrie and Hugh Stephenson (1997). Libel and the Media: The Chilling Effect. Oxford: Oxford University Press.

Bernays, Edward L. (1983). Interview, The Image Makers (VHS videotape) produced and directed by David Grubin, Washington, DC, distributed by PBS Video.

Cadzow, Jane (2003, August 16). Out on a limb. Good Weekend (Magazine of the Sydney Morning Herald), pp 18-22.

Carey, Alex (1995).Taking the Risk out of Democracy: Corporate Propaganda versus Freedom and Liberty. Urbana: University of Illinois Press.

Dawson, Christopher (1986, March 26). Free speech defended as pro-Hitler man is gagged. The Australian, p 13.

De Maria, William (1999). Deadly Disclosures: Whistleblowing and the Ethical Meltdown of Australia. Adelaide: Wakefield Press.

Evans, Richard J.(2001). Lying about Hitler: History, Holocaust and the David Irving Trial. New York: Basic Books.

Ewen, Stuart (1976). Captains of Consciousness: Advertising and the Social Roots of Consumer Culture. New York: McGraw-Hill.

Ewen, Stuart (1996). PR! A Social History of Spin. New York: Basic Books.

Ewing, David W. (1977). Freedom Inside the Organization: Bringing Civil Liberties to the Workplace. New York: E.P. Dutton.

Frankel, Philip (2001). An Ordinary Atrocity: Sharpeville and its Massacre. New Haven, CT: Yale University Press.

Franken, Al (2003). Lies and the Lying Liars Who Tell Them: A Fair and Balanced Look at the Right. New York: Dutton.

Giles, Jim (2003). The man they love to hate. Nature 423 (15 May): 216-218.

Grossman, Wendy M. (1995). alt.scientology.war. Wired 3(12), December: 172-177, 248-252.

Henderson, Gerard (2003, September 9). Whistleblower dreaming if he didn't expect flesh wounds. Sydney Morning Herald, p 13.

Herman, Edward S. and Noam Chomsky (1988). Manufacturing Consent: The Political Economy of the Mass Media. New York: Pantheon.

Herszenhorn, David M. (2003, July 26). Hospital drops legal action to stem tide of bad publicity. New York Times, p B5. 


\section{THE PUBLIC RIGHT TO KNOW}

Hirschkorn, Phil (2003, August 23). Fox loses attempt to block satirist's book. CNN.com.

Jansen, Sue Curry (1988). Censorship: The Knot that Binds Power and Knowledge. New York: Oxford University Press.

Jansen, Sue Curry and Brian Martin (2003). Making Censorship Backfire. Counterpoise 7(3): 5-15.

Johnson, Peter Amanpour (2003, September 14). CNN practiced self-censorship. USA Today.

Keane, John (1991). Media and Democracy, London: Polity Press.

Krugman, Paul (2003, October 3). Slime and defend. New York Times.

Lippmann, Walter (1922). Public Opinion. New York: Macmillan.

Lippmann, Walter (1925/1995). The Phantom. In Jackall, Robert and Janice M. Hirotapp (eds), Propaganda (pp 47-53). New York: New York University Press.

Lomborg, Bjørn (2001). The Skeptical Environmentalist: Measuring the Real State of the World. Cambridge: Cambridge University Press.

Martin,Brian (2002). Dilemmas of defending dissent: the dismissal of Ted Steele from the University of Wollongong. Australian Universities' Review 45(2): 7-17.

Martin, Brian and Steve Wright (2003). Countershock: mobilizing resistance to electroshock weapons. Medicine, Conflict and Survival 19(3): 205-22.

Mercer, Neil (2003a, July 29). Petty thieves beware: the untouchables could seize your home. Sydney Morning Herald, pp 1, 4.

Mercer, Neil (2003b, July 31). They just stitch you up: verdict on secret police. Sydney Morning Herald, p 7.

Milliken, Robert (1993, May 23). Irving enlists video Nazis to attack ban on Australia visit. The Independent, p 18.

Pring, George W. and Penelope Canan (1996). SLAPPs: Getting Sued for Speaking Out. Philadelphia: Temple University Press.

Pryor, Lisa and Justin Vallejo (2002, December 21-22). Murder the PM, he wrote, risking his HSC. Sydney Morning Herald, pp 1, 4.

Pullan, Robert (1994). Guilty Secrets: Free Speech and Defamation in Australia. Sydney: Pascal Press.

Rich, Frank (2003, September 21). The greatest story ever sold. New York Times.

Schoenbrod, David (2002). The Mau-Mauing of Bjørn Lomborg. Commentary, 114 (September): 51-53.

Seccombe, Mike (2003, September 11). Howard's rottweilers still biting at the heels of whistleblower. Sydney Morning Herald, p. 7.

Sennett, Richard. (1980). Authority. New York: Knopf.

Sharp, Gene (1973). The Politics of Nonviolent Action. Boston: Porter Sargent.

Smythe, Dallas W. (1981). Dependency Road: Communications, Capitalism, Consciousness, and Canada. Norwood, NJ: Ablex.

Soley, Lawrence (2002). Censorship, Inc.: The Corporate Threat to Free Speech in the United States. New York: Monthly Review Press.

Stauber, John, and Sheldon Rampton (1995). Toxic Sludge is Good for You. Monroe, ME: Common Courage Press. 
Tye, Larry (1998). The Father of Spin: Edward L. Bernays and the Birth of Public Relations. New York: Crown Publishers.

Williams, Kipling D. (2001). Ostracism: The Power of Silence. New York: Guilford Press.

Dr Sue Curry Jansen is a Professor in the Communication Department, Muhlenberg College, Allentown, PA, United States, and Dr Brian Martin is Associate Professor in Science, Technology and Society at the University of Wollongong, NSW, Australia. Dr Martin is also International Director of Whistleblowers Australia. A version of this article was presented at the third Public Right to Know (PR2K3) conference at the University of Technology, Sydney, 18 October 2003. The authors thank Don Eldridge and an anonymous referee for helpful comments on drafts. This work was supported by the Australian Research Council.

jansen@muhlenberg.edu

bmartin@uow.edu.au

www.uow.edu.au/arts/sts/bmartin/ 